\section{New site records of Gegeneophis goaensis and G. mhadeiensis (Gymnophiona: Caeciliidae) from the Western Ghats of Goa and Karnataka}

\author{
Gopalakrishna Bhatta ${ }^{1}$, K.P. Dinesh ${ }^{2}$, \\ P. Prashanth ${ }^{3}$, Nirmal U. Kulkarni ${ }^{4}$ \& \\ C. Radhakrishnan ${ }^{5}$
}

${ }^{1}$ Department of Biology, BASE Educational Service Pvt. Ltd., Basavanagudi, Bengaluru, Karnataka 560004, India

2,5 Zoological Survey of India, Western Ghat Regional Centre, Eranhipalam, Kozhikode, Kerala 673006, India

${ }^{3}$ Agumbe Rainforest Research Station, Agumbe, Karnataka 577411, India

${ }^{4}$ Hiru Naik Building, Dhuler Mapusa, Goa 403507, India

Email: ${ }^{2}$ dineshcafe@gmail.com (corresponding author)

In India the order Gymnophiona Müller is represented by 26 species under four genera in two families (Dinesh et al. 2009). The genus Gegeneophis Peters is endemic to India with 10 species, one endemic to northeastern India and the remaining nine restricted to the Western Ghats (Fig. 1). During the past six years seven new species were discovered in the northern and central parts of the Western Ghats (between $17^{\circ} 01^{\prime} \mathrm{N}-12^{0} 59^{\prime} \mathrm{N}$ ) (Pillai \& Ravichandran 1999; Giri et al. 2003; Ravichandran et al. 2003; Bhatta \& Prashanth 2004; Bhatta \& Srinivasa 2004; Bhatta et al. 2007a \& Bhatta et al. 2007b). This

Date of publication (online): 26 July 2010

Date of publication (print): 26 July 2010

ISSN 0974-7907 (online) | 0974-7893 (print)

Editor: Sanjay Molur

Manuscript details:

Ms \# 02364

Received 10 December 2009

Final received 09 April 2009

Finally accepted 30 June 2010

Citation: Bhatta, G., K.P. Dinesh, P. Prashanth, N.U. Kulkarni \& C. Radhakrishnan (2010). New site records of Gegeneophis goaensis and G. mhadeiensis (Gymnophiona: Caeciliidae) from the Western Ghats of Goa and Karnataka. Journal of Threatened Taxa 2(8): 1105-1108.

Copyright: () Gopalakrishna Bhatta, K.P. Dinesh, P. Prashanth, Nirma U. Kulkarni \& C. Radhakrishnan 2010. Creative Commons Attribution 3.0 Unported License. JoTT allows unrestricted use of this article in any medium for non-profit purposes, reproduction and distribution by providing adequate credit to the authors and the source of publication.

Acknowledgements: GB is thankful to the Department of Science and Technology, Govt. of India and Director, BASE, Bangalore for encouraging research on caecilians of Western Ghats. DKP and CR are grateful to Dr. Ramakrishna, Director, Zoological Survey of India, Kolkata for facilities. PP thanks the Director, ARRS, Agumbe for encouragement. We thank Luma Gaonkar of Chorla Village and Namdev Gaonkar of Surla Village for their field support.

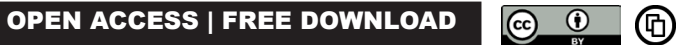

upsurge in the description of new species in Gegeneophis may be due to optimization of surveying techniques, and recent predictions (Dinesh et al. 2009) indicate future discovery of new species from this genus.

Gegeneophis goaensis was described by Bhatta et al. (2007a) from Keri Village, Sattari Taluk, North Goa District, Goa based on a set of three specimens collected in September 2006 and July 2008. G. mhadeiensis was described in 2007 from Chorla Village, Khanapur Taluk, Belgaum District, Karnataka from a set of three specimens collected during 2006 (Bhatta et al. 2007b). During our recent explorations for these secretive animals in the bordering districts of Maharashtra (Sindhudurg), Goa (North Goa) and Karnataka (Belgaum), we collected an individual of $G$. goaensis (Image 1) below the soil heap surrounding a banana plantation in Chorla Village (Karnataka) on 05 August 2009 (Table 1). All the morphological and morphometric details were in agreement with the description of Bhatta et al. (2007a). Morphometric and meristic variations noted in the vouchered specimen deposited at the Zoological Survey of India (ZSI), Kozhikode, Kerala (ZSI/WGRC/V/A/714) are presented in Table 3 . The specimen has 121 primary annuli; secondary annuli making their appearance at the $76^{\text {th }}$ primary annulus and the total number of secondary annuli accounting to 46 . The other congeneric species found sympatric is G. mhadeiensis. Earlier Bhatta et al. (2007a) reported G. goaensis from Keri Village (Goa) at an altitude of $21 \mathrm{~m}$ and the present report from Chorla Village (Karnataka) is a new site record from a much higher altitude of $780 \mathrm{~m}$. The present site record extends the distribution range further north by $20 \mathrm{~km}$ from the type locality. The specimen collected is deposited at the national depository of ZSI, Kozhikode.

Between 5-7 August 2009, we collected five individuals of Gegeneophis resembling each other from three different localities of the above mentioned districts (Table 2). They were collected in homestead areas, alongside the man-made cow dung manure pits, under waste straw heaps and at the base of banana plantations. Laboratory studies confirmed the identity of these five individuals as G. mhadeiensis (Image 2). Field identification of these individuals was relatively difficult because of their superficial external resemblance with the congeneric species G. carnosus, G. krishni and young ones of $G$. nadkarnii. Morphometric and meristic variations noted in the vouchered specimens (ZSI/WGRC/V/A/715; 713a \& 713b; 716a \& 716b) are presented in the Table 3 . In the studied specimens, primary annuli ranged from 118 to 125; secondary annuli made their appearance in the range of $87^{\text {th }}$ to $98^{\text {th }}$ primary annuli and the total number of secondary annuli were in the range of 24 to 32 . The two individuals collected from Maan (Karnataka) were 


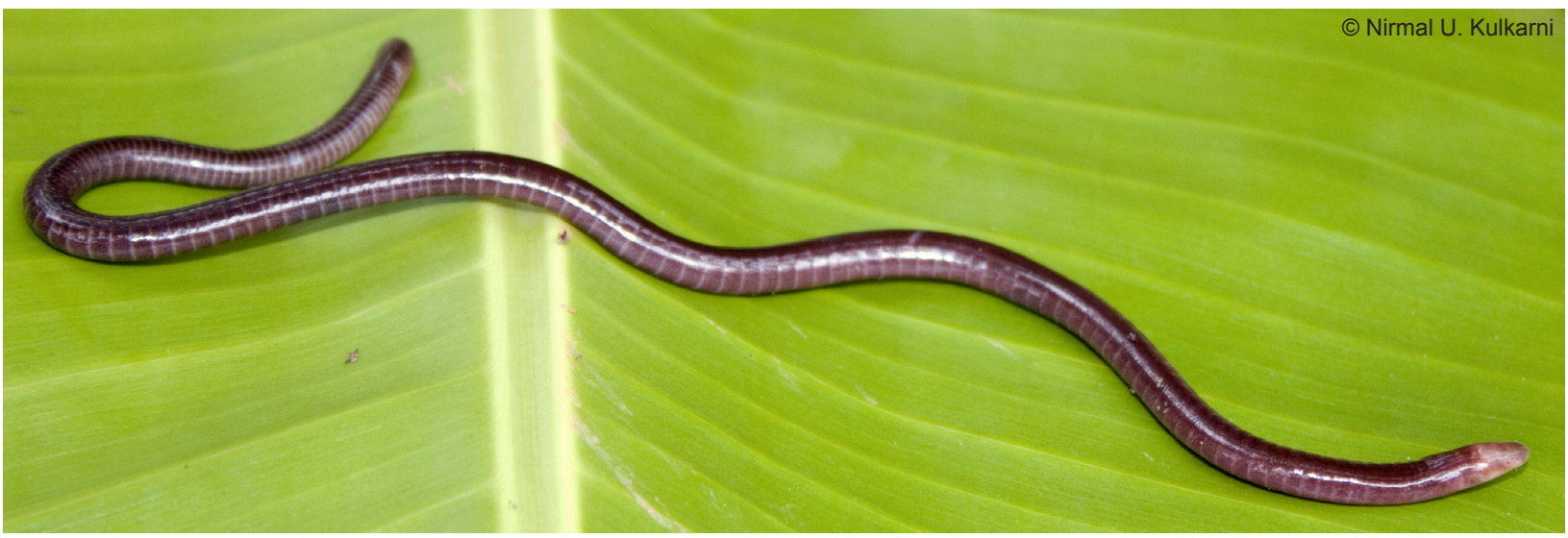

Image 1. Gegeneophis goaensis in life from Chorla Village, Karnataka (ZSI/WGRC/VIA/714)

Table 1. Collection localities for G. goaensis in Goa State.

\begin{tabular}{|c|c|c|c|c|}
\hline SNo & Registration No. & $\begin{array}{c}\text { Collection } \\
\text { locality }\end{array}$ & $\begin{array}{c}\text { Latitude } \\
\text { Longitude }\end{array}$ & $\begin{array}{c}\text { Altitude } \\
\text { (a msl) }\end{array}$ \\
\hline 1 & $\begin{array}{l}\text { BNHS 4594 (holotype) } \\
\text { BNHS 4595 (paratype) }\end{array}$ & $\begin{array}{c}\text { Keri } \\
\text { (Goa) }\end{array}$ & $\begin{array}{c}15^{\circ} 21^{\prime} 36^{\prime \prime} \mathrm{N} \\
74^{\circ} 02^{\prime} 24^{\prime \prime} \mathrm{E}\end{array}$ & 21 \\
\hline 2 & $\begin{array}{l}\text { ZSI/WGRC/N/A/714 } \\
\text { (present collection) }\end{array}$ & $\begin{array}{c}\text { Chorla } \\
\text { (Karnataka) }\end{array}$ & $\begin{array}{c}15^{\circ} 39^{\prime} \mathrm{N} \\
74^{\circ} 08^{\prime} 24^{\prime \prime} \mathrm{E}\end{array}$ & 780 \\
\hline
\end{tabular}

robust when compared to other individuals from Chorla (Karnataka) and Surla (Goa). During our surveys in these localities, the very common sympatric species of caecilian, G. nadkarnii was sighted.

On 08 August 2009 at Keri Village (Goa), we found a good population of $G$. goaensis within a $2-\mathrm{km}$ radius of the type locality. No individuals were collected from this site. Here, Ichthyophis bombayensis was found to be sympatric with G. goaensis.

Although caecilians are often considered rare and thought to require pristine habitat (Gower \& Wilkinson 2005), our present study reveals that systematic search in a suitable habitat with decomposing organic matter can yield good caecilian collections and also in synanthropic

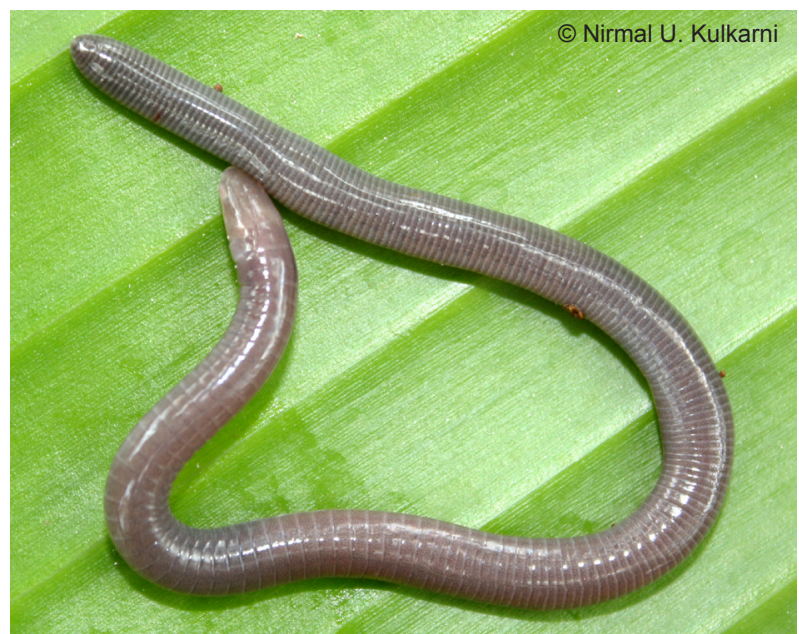

Image 2. Gegeneophis mhadeiensis in life from Maan Village, Karnataka

environments. In India, systematic caecilian studies are recent, with most earlier museum collections being opportunistic. It is considered that most of the new species described since 1999 are documented from a few individuals. In this context, our endeavours in the

Table 2. Collection localities for G. mhadeiensis bordering Karnataka and Goa states.

\begin{tabular}{|c|c|c|c|c|c|}
\hline SNo & Registration No. & Collection locality & Latitude (N) & Longitude (E) & Altitude (in m) \\
\hline 1 & $\begin{array}{l}\text { BNHS } 4643 \text { (holotype) } \\
\text { ZSI/WGRC/VIA/640 (paratype) } \\
\text { BNHS } 4644 \text { (paratype) }\end{array}$ & Chorla (Karnataka) & $15^{0} 23^{\prime} 24^{\prime \prime}$ & $74^{\circ} 08^{\prime}$ & 728 \\
\hline 2 & $\begin{array}{l}\text { ZSI/WGRC/VIA/715 } \\
\text { (present collection) }\end{array}$ & Chorla (Karnataka) & $15^{0} 39^{\prime} 27^{\prime \prime}$ & $74^{\circ} 08^{\prime} 36^{\prime \prime}$ & 780 \\
\hline 3 & $\begin{array}{l}\text { ZSI/WGRC/VIA/713a \& 713b } \\
\text { (present collection) }\end{array}$ & Surla (Goa) & $15^{\circ} 40^{\prime} 19^{\prime \prime}$ & $74^{0} 10^{\prime} 24^{\prime \prime}$ & 750 \\
\hline 4 & $\begin{array}{l}\text { ZSI/WGRC/VIA/716a \& 716b } \\
\text { (present collection) }\end{array}$ & Maan (Karnataka) & $15^{\circ} 09^{\prime} 8^{\prime \prime}$ & $74^{\circ} 09^{\prime} 08^{\prime \prime}$ & 712 \\
\hline
\end{tabular}


Table 3. Some morphometric (in $\mathrm{mm}$ ) and meristic data for G. goaensis and G. mhadeiensis. Measurements were made to the nearest $0.1 \mathrm{~mm}$ with dial calipers, except for length and circumference, which were measured with a ruler and a piece of thread.

\begin{tabular}{|c|c|c|c|c|c|c|}
\hline ZSI/WGRC/VIA/ & *714 & ${ }^{\wedge} 713 a$ & ^713b & ${ }^{\wedge} 715$ & ${ }^{\wedge} 716 a$ & ^716b \\
\hline Total length & 208 & 192 & 211 & 179 & 235 & 223 \\
\hline Head length & 4.43 & 4.38 & 4.71 & 3.48 & 5.77 & 5.02 \\
\hline Head width at jaw angle & 3.41 & 3.26 & 3.45 & 3.07 & 4.03 & 3.8 \\
\hline Circumference at mid body & 16 & 17 & 17 & 13 & 21 & 21 \\
\hline Width of the body at 1 st annular groove & 3.53 & 4.23 & 4.52 & 3.3 & 4.36 & 4.23 \\
\hline Width of the body at broadest region & 4.05 & 5.02 & 5.61 & 3.64 & 5.8 & 5.37 \\
\hline Width of the body at the level of vent & 3.17 & 3.14 & 3.37 & 2.51 & 2.86 & 3.39 \\
\hline Length divided by width & 51.35 & 38.24 & 37.61 & 49.17 & 40.51 & 41.52 \\
\hline Length of the snout projecting beyond mouth & 1.16 & 1.05 & 1.36 & 1.06 & 1.14 & 1.53 \\
\hline Distance between jaw angle and top of head & 1.27 & 1.26 & 1.21 & 1.27 & 1.9 & 1.55 \\
\hline Distance between jaw angle and ventral surface of lower jaw & 1.57 & 1.49 & 1.34 & 1.02 & 1.36 & 1.3 \\
\hline Distance between jaw angle and tip of lower jaw & 3.58 & 3.15 & 3.79 & 3.19 & 4.91 & 4.35 \\
\hline Distance between nostrils & 1.77 & 1.49 & 1.86 & 1.61 & 1.77 & 1.9 \\
\hline Distance between nostril and snout tip & 0.98 & 0.83 & 0.94 & 1 & 1.02 & 1.04 \\
\hline Distance between tentacles & 2.54 & 2.62 & 2.95 & 2.46 & 3.41 & 2.9 \\
\hline Distance between tentacle and snout tip & 1.94 & 2.24 & 2.55 & 2.13 & 2.51 & 2.2 \\
\hline Distance between tentacle and jaw angle & 2.55 & 2.51 & 2.86 & 2.28 & 3.11 & 3.45 \\
\hline Distance between tentacle and nostril & 1.26 & 1.43 & 1.42 & 1.08 & 1.69 & 1.56 \\
\hline Distance between tentacle and margin of upper lip & 0.88 & 0.67 & 0.85 & 0.67 & 0.72 & 0.68 \\
\hline Distance between tentacle and top of head & 0.83 & 0.65 & 0.8 & 1 & 1.55 & 1.3 \\
\hline Width at 1 st nuchal groove & 3.76 & 3.85 & 4.03 & 3.09 & 4.29 & 3.91 \\
\hline Width at 2 nd nuchal groove & 3.8 & 4.04 & 4.33 & 2.92 & 4.12 & 3.62 \\
\hline Length of 1st collar (laterally) & 2 & 1.54 & 1.83 & 1.9 & 1.46 & 1.84 \\
\hline Length of 2nd collar (laterally) & 1.84 & 1.92 & 2.37 & 2 & 2.76 & 2.7 \\
\hline Dist. between snout tip and 1st nuchal groove & 5.71 & 5.25 & 6.16 & 4.98 & 6.86 & 6.29 \\
\hline Distance between snout tip and 2nd nuchal groove & 6.91 & 6.29 & 6.96 & 6.43 & 8.2 & 7.59 \\
\hline Distance between snout tip and 3rd nuchal groove & 8.48 & 7.98 & 9.6 & 7.79 & 10.57 & 9.82 \\
\hline Total number of primary annuli & 121 & 118 & 121 & 121 & 122 & 125 \\
\hline Total number of primary annuli with secondary grooves & 46 & 32 & 28 & 24 & 30 & 27 \\
\hline Anterior most primary annulus with secondary groove & 76 & 87 & 94 & 98 & 93 & 98 \\
\hline No. of complete secondary annuli in front of vent & 7 & 7 & 8 & 8 & 8 & 7 \\
\hline Width of disc surrounding vent & 1.44 & 1.47 & 2.4 & 1.27 & 2.39 & 2.19 \\
\hline Length of disc surrounding vent & 0.6 & 0.85 & 0.8 & 0.82 & 1.11 & 0.86 \\
\hline Width of vent & 1.41 & 1.08 & 1.63 & 1.13 & 2 & 1.84 \\
\hline Number of denticles surrounding the vent & 6 & 7 & 6 & 7 & 7 & 6 \\
\hline
\end{tabular}

* G. goaensis; ^ G. mhadeiensis 


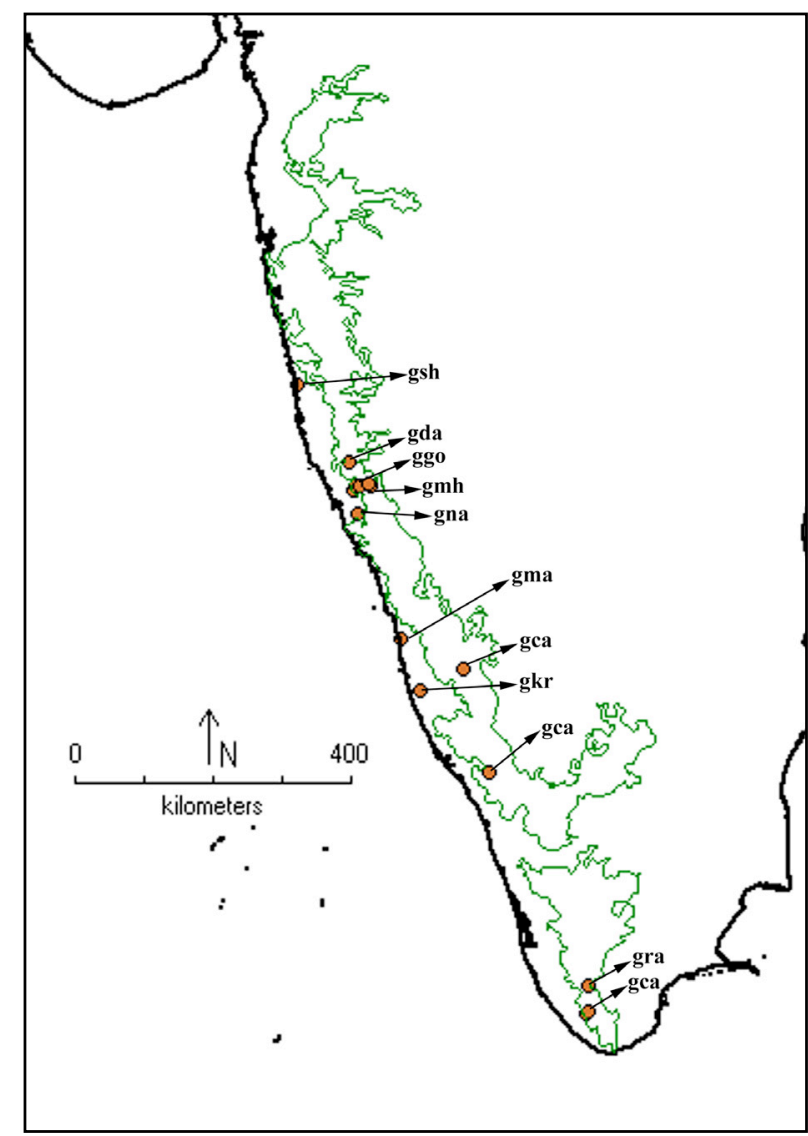

Figure 1. Distribution of species of Gegeneophis in Western Ghats gsh - Gegeneophis seshachari; gda - Gegeneophis danieli; ggo - Gegeneophis goaensis; gmh - Gegeneophis mhadeiensis gna - Gegeneophis nadakarnii; gma - Gegeneophis madhavai; gca - Gegeneophis carnosus; gkr - Gegeneophis krishni; gra - Gegeneophis ramaswamii

past (Bhatta et al. 2007c) and the present collections not only yield a good number of specimens, but also provide ample insights into the consistency in adoption of annuli count as a key character in caecilian (Gegeneophis) taxonomy.

Distribution and taxonomic data of caecilians are felt to be inadequate since most are poorly known. Our studies reveal sympatric associations between $G$. nadkarnii, $G$. goaensis, G. mhadeiensis and I. bombayensis. Among the seven new species described in the past six years, we have natural history only for $G$. seshachari Ravichandran et al., 2003 (Gower et al. 2008). Since G. nadkarnii Bhatta \& Prashanth, 2004, G. goaensis and G. mhadeiensis are now known from different localities our data is expected to promote further studies on the natural history of caecilians.

\section{REFERENCES}

Bhatta, G. \& P. Prashanth (2004). Gegeneophis nadakarnii - a caecilian (Amphibia: Gymnophiona: Caeciliidae) from Bondla wild life sanctuary, Western Ghats. Current Science 87(3): 388-392.

Bhatta, G. \& R. Srinivasa (2004). A new species of Gegeneophis Peters (Amphibia: Gymnophiona: Caeciliidae) from the surroundings of Mookambika Wildlife Sanctuary, Karnataka, India. Zootaxa 644: 1-8.

Bhatta, G., K.P. Dinesh, P. Prashanth \& N.U. Kulkarni (2007a). A new species of Gegeneophis Peters (Amphibia: Gymnophiona: Caeciliidae) from Goa, India. Zootaxa 1409: 51-59.

Bhatta, G., K.P. Dinesh, P. Prashanth \& N.U. Kulkarni (2007b). A new species of the Indian caecilian genus Gegeneophis Peters (Amphibia: Gymnophiona: Caeciliidae) from the surroundings of Mahadayi Wildlife Sanctuary, Western Ghats. Current Science 93(10): 1442-1445.

Bhatta, G, K.P. Dinesh, P. Prashanth \& N.U. Kulkarni (2007c). On the distribution, morphology and morphometry of Gegeneophis nadkarnii Bhatta and Prashanth, 2004 (Gymnophiona: Caeciliidae) from Goa. Biosystematica 1(1): 71-74.

Dinesh, K.P., C. Radhakrishnan, K.V. Gururaja \& G. Bhatta (2009). An annotated checklist of Amphibia of India with some insights into the patterns of species discoveries, distribution and endemism. Records of Zoological Survey of India, Occasional Paper No. (302): 1-152pp.

Giri, V., M. Wilkinson \& D.J. Gower (2003). A new species of Gegeneophis Peters (Amphibia: Gymnophiona: Caeciliidae) from southern Maharastra, India, with a key to the species of the genus. Zootaxa 351: 1-10.

Gower, D.J. \& M. Wilkinson (2005). Conservation Biology of Caecilian Amphibians. Conservation Biology 19: 45-55.

Gower, D.J., V. Giri, M.S. Dharne \& Y.S. Shouche (2008). Frequency of independent origins of viviparity among caecilians (Gymnophiona): evidence from the first 'livebearing' Asian Amphibian. Journal of Evolutionary Biology 21: 1220-1226.

Pillai, R.S. \& M.S. Ravichandran (1999). Gymnophiona (Amphibia) of India. A taxonomic study. Records of the Zoological Survey of India, Occasional Papers 172: 1-117.

Ravichandran, M.S., D.J. Gower \& M. Wilkinson (2003). A new species of Gegeneophis Peters (Amphibia: Gymnophiona: Caeciliidae) from Maharastra, India. Zootaxa 350: 1-8. 